\title{
ENTRY OPPORTUNITIES IN THE BULGARIAN MILITARY- EDUCATIONAL SYSTEM AND ENSURING OF CIVIL RIGHTS
}

\author{
Venelin Terziev $^{1}$ and Veselin Madanski ${ }^{2}$ and Dimitar Kanev ${ }^{3}$ \\ ${ }^{1}$ Prof., Ph.D., D.Sc. (National Security), D.Sc. (Ec.), University of Rousse, Bulgaria, \\ National Military University, Veliko Tarnovo, Bulgaria, \\ University of Telecommunications and Post, Sofia, Bulgaria \\ ${ }^{2}$ Colonel, Associate Professor, D.Sc., P.h.D., National Military University, Veliko Tarnovo, \\ Bulgaria \\ ${ }^{3}$ Professor, D.Sc. (Ec.), Ph.D.Nikola Vaptsarov Naval Academy, Varna, Bulgaria
}

\begin{abstract}
The report presents all current challenges which the Bulgarian military -educational system is facing in the context of the basic features of the security environment and trends for the first half of the $20^{\text {th }}$ century, by identifying the main problem areas in its functioning. The status and the capabilities of the military educational system of the Republic of Bulgaria are discussed on the basis of conducted analysis about key strategic documents in the sectors of education, security and defence, as well as the current state of the military and civil education and the inherent activities of the training institutions. Outlined are the basic principles of construction and operation of the military - educational systems and the fundamental strategic goals and tasks according to modern strategic security environment and dynamically changing conditions in NATO and the EU. Described are the main elements of the military - educational system as a complex, adaptive and flexible system that develops in unity and complementarity with the system of civil education in Bulgaria. Guidelines are formulated for improving the military - educational system in relation to its contribution to strengthening national security and defence of the country in three directions - conceptual, organizational and technological improvement.
\end{abstract}

Keywords: education, military education, training, civil rights, security

\section{INTRODUCTION}

Modern world acknowledges the significance of quality education. In the Lisbon Strategy Europe declares the necessity of long-term investments in education. Each country needs enough and well educated human resources as a fundamental prerequisite for enhancing national security. The concept for national security defines national security as a dynamic status, where there is no direct danger of armed attack, political pressure or economical compulsion for the state as well as for the society, so that they can freely realize their development and progress. Specific problematic areas that have political, economic, social, ethnic, spiritual, military, information and ecological components are inherent for the national security. Each one of 
these components, independently or in combination with the others, as well as with number of side (secondary) factors may turn crucial for the national security and all of them are characterized by being, one way or another, dependent on the human resources' level of education. The great problem of our society today is the setting up of clear and correct policy in the field of education and science, taking into consideration the requirements of the national security system. The employed in the field of security and defence occupy specific knowledge and skills, acquired through special education, practical experience, skill and individual improvement in work. This defines education to be fundamental element of the human resources preparation, which ensures the appropriate knowledge, skills and competences. We could say, in that very context, that country's educational system has significant contribution to the national security, contributing to enhancing the erudition, competence, forming appropriate skills and capacity, acquiring adequate qualification as well as quite a significance regarding personal progress. Educational system should be referred to as a subsystem of the national security system and the military-educational system (MES) is its basic element.

\section{CONTEMPORARY CHALLENGES THE MILITARY-EDUCATIONAL SYSTEM OF THE REPUBLIC OF BULGARIA FACES}

Security strategic environment is complex, dynamic and possessing hardly foreseeable dimensions. The following factors and circumstances influence its forming: globalization; crisis phenomena in the field of finances and economics; spreading of mass destruction weapons and of the means for their supply; the climatic, health, demographic, ecological and energy problems; ethno-social and asymmetric risks and threats; threats for the information security; countries with weak systems of state; interior and regional conflicts; the European and Euro-Atlantic integration; international democratic community's efforts for maintaining peace and stability (2016).

The listed processes, factors and momenta form the main features of the security environment and enable the definition of the major trends in its development during the first half of the $21^{\text {st }}$ century. We will dwell on the more important characteristics of the security environment.

First, its significant characteristics, which was unknown till the end of the $20^{\text {th }}$ century, is the extending globalization. The processes of globalization influence inevitably the forming of security environment various aspects. They create conditions for development of the connections between the countries but also deepen the economical and social inequality, the disbalance of countries' progress and the demographic disproportions.

Second, perhaps as a result of globalization, ethno-social, asymmetric and other transnational risks and threats occur constantly. Recently, these have crucial impact on the strategic security environment and terrorism is considered major threat for the global, regional and national security. Terrorist organizations decentralize their structures, which makes their single elements' localization and neutralization difficult. The possibilities and probabilities for them to use means like radioactive materials, chemical and biological agents increase.

We can point the occurrence of transnational organized criminality and illegal human, drug and weapon trafficking as third important characteristics of the security environment. They threaten not only countries stability but also the world economic order, and complicate the strategic security order. A characteristic feature of security environment globally is that the radical Islamic organizations use the Internet space not only for attracting followers and recruiting new members but for conducting information war, too. They apply the newest information and communication technologies with the strategic goal to disseminate the global impact of their religion, fighting for the mind and hearts of people, including the ones in the Internet space. Global web network is the space in this process, where permanent fight for ideology dissemination and attraction of new followers is going on as well as attracting people from other religions. The reasons for using the Internet space are its comprehensiveness, its speed and its secure way of information dissemination.

Four, the financial and economic crisis that occurred as well as the negative trends prove the economic stability being very fragile. As a result of the global economic inter-binding between the economies of various countries, unions and regions, the world is already globally dependant and super-sensitive towards any negative economical and financial processes or any disturbance in the rhythm of resources, goods or services supplies. Any similar phenomenon in the world has immediate negative effect upon the countries' interior stability and international relationship as well as upon the sector of security and defence.

Five, climate changes, occurring natural anomalities and calamities and the wide reading of dangerous illnesses complicate additionally the existing problems - poverty, social tension, ecological situation, and threaten the governance and stability of countries. They create objective prerequisites for interior conflicts 
and humanitarian crisis, which require allocation of good civil, financial and military resources for their solving.

Six - The problems connected to the emerging and speeding up lack of energy and natural resources turn into more and more serious challenge for all economically developed countries. Energy security acquires new dimensions and the risks and threats in that field result from the enhanced collision of interests, the presence of unsolved conflicts in the regions of deriving and transport of resources and the actions of terrorist groups and armed formations.

Seven, the risks for the information security and the threats of cyber attacks against strategic civil and military communication-information systems and powers participating in missions and operations outside the country's territory sharply rise. They result from the dynamic technologies development, the widening of the circle of criminal and extremist organizations and hackers, who try to get illegal; access to classified information, which has been created, processed, stored and transferred through automated information systems and networks.

These characteristics of the security environment development outline also some trends, characteristic of the $21^{\text {st }}$ century, which influence directly the military-educational system of the country. The most important of them could be defined as follows:

- The security environment's military aspects do not fade but acquire new dimensions as a result of political changes in the world and Europe, of the widening the scope of asymmetric risks and threats and of the waning of the significance of some factors that influenced the missions and the preparation of the armed forces in the past. The threats of a big international military conflict arising is significantly reduced because of lack of inter-blocks confrontation and of the imposed necessity of interaction between the countries for neutralization of contemporary risks and threats. Yet, regional centres of tension and stability still exist, where military resources are inevitably involved.

- A clear global trend and specific negative factor for the condition of Bulgarian military-educational system at present is the fact that the world and the country are in a period of worsening demographic progress. World's population is ageing; it is reducing in the "rich" Western countries and increases only in some countries in Asia, the Muslim countries in the Near East and the Asian-Pacific region and Latin America. Bulgarian population registers continuing trend of reducing as a result of the negative growth and the intense migration the last thirty years.

- This leads to the inevitable reduction of the people finishing high school and therefore reduction of the number of potential candidate students for the higher military schools. This factor reflects also on the impossibility for filling up the members of the lecturers' staff with young well-prepared and perspective cadres, and these result in the continuing ageing of the academic members, precisely the academically ranked lecturers, who are providers of the most valuable - knowledge and traditions of Bulgarian militaryeducational system.

- Next clearly unfavourable trend that has to deal with the military-educational system's functioning is the limiting of military budgets globally and the reduction of armed forces number, which leads to considerable reduction of possibilities for the military forces to be completed with young officers. Actually, insufficient financing is an extremely unfavourable factor for the functioning and progressing of the military-educational system on a national scale. The consequences from the economical crisis as well as the severe financial restraints have inevitable negative impact upon the funds for social expenses and transport, healthcare, education and scientific studies, as well as upon the funding of the security system and particularly the defence of the country within the frame of considerably complicated military budget. This trend in the military-educational functioning environment imposes the latter to function and progress in conditions of financial restraints (even serious deficits) and armed forces discharging.

- It is necessary to consider also the materially outlining trend for the military academies and schools to function in highly competitive market environment of higher education alongside the other educational institutions in the country, including the similar ones in the region, NATO and EU. The competitiveness on the higher education market leads to natural competition in offering educational and scientific research services in the sector of security and defence. Civil higher schools enter in educational and training fields traditionally considered "military": national and regional security; management of defence resources; protection of population and critical infrastructure; management of crisis; management of air traffic; training of pilots, etc. Trends for drawing intellectual potential away and expertise flowing is observed in the competition mentioned, from military schools towards civil universities. This is a signal for giving new meaning to the policy of creating and retaining science cadres, of keeping already „gained territories” as well as of extending 
the scope and establishing indisputable leader position in the education of cadres in the fields connected to national security and defence.

Two problematic areas can be defined in the general context of analysis of these processes:

The first one - is unprepared for "showing off" and functioning of the academic staff in the "new" and dynamically changing environment. Meaning that the development of academic staff of MES has developed according other and specific rules until now, where proving its competences, skills and abilities depended on certain rules and restrictions. This process now is subject to general dependences, to factors and processes that are not determined only by the interior MES environment. This puts the lecturers with academic rank and the ones without in a sharply competitive environment, and in some cases - an environment of no definite rules (meaning not only the market principles).

The second one - is that the civil educational system is opened towards the outside environment long ago and this process progresses considerably fastly - i.e. it has offered its scientific product, has succeeded in commercializing its scientific and scientific-applied results, which puts her in a different position. Scientific research and development activities are vaguely known in the higher military educational institutions, even unknown for the „narrow” academic community, and thinking for its realization outside the immediate field of applying at this point is almost inconceivable.

To summarize, we can point that researchers, experts and political analysts are unanimous that contemporary security environment is a way far complicated, unpredictable and full of risks and threats of various nature, origin, direction and power of effect. Today, when the world is in a new spiral or geopolitical transformation, these risks and threats are cause for regional instability and unstable development, for the occurrence and sharpening of conflicts of ethnic and religious origin, for the globalization of organized criminality and the connected forms of terrorism more than ever.

As it was already pointed, the distribution of weapons for mass destruction, international terrorism, the instability in the "disintegrating" countries, ecological and humanitarian disasters, the threats for the energy security, transnational criminality as well as the possibility for armed aggression in certain regions of the world are among the most complicated problems we are facing today (2013).

World entered the so called "information era”, where globalization and the information technologies "obliterated" countries' borders and globalized society's security, made rapid changes in its social structures, relations and behaviour. These new conditions made us witness extremely devastating natural calamities and cataclysms, bloody social and ethnic conflicts and freezing manifestations of extremism and terrorism all over the world in real time, and on the other hand these imposed new requirements for prevention and adequate anti-crisis abilities for the security systems (2013).

The deficit of energy, raw materials and water resources, the crisis financial phenomena and the worsen economical effect, in combination with the demographic disbalance worldwide lead to speeding up the migration and state power going down. Political instability, poverty and misery, ethnic and religious conflicts on their side lead to setting up of regions of instability and unstable development.

These processes result in loss of statehood and in disintegrating countries, which creates favourable environment for international and interior terrorism, organized criminality and drug traffic, mass hunger, epidemics and ecological catastrophes.

On the other hand, international democratic community experts efforts for maintaining the peace and stability in the crisis regions and on a global scale, and as additional trends European and Euro Atlantic integration, cooperation and sharing of possibilities for joint defence outline.

The listed factors, conditions, characteristics and trends do not exhaust completely the special features of the security environment, where MES functions but have decisive impact on its mission, goals, structure and forms of training as well as they make it face number of challenges and a complicated complex of requirements.

The sector for security and defence on one hand, and education on the other hand are among the most important social institutes of the state and the statehood, and military education is their crucial composite element. According to the Strategy for development of the system for education and qualification of the professional military servicemen from the Armed Forces (AF) of the Republic of Bulgaria of 2006, the MES environment of functioning is determined by: the missions and tasks of AF; the legal order; the socialeconomic relations; the information technologies; the demographic development and county's membership in NATO and the EU [6]. Substantial changes occurred in each of the environment's elements in the recent years and satisfying the new requirements is the main challenge that the military-educational system faces. 
It is a universally recognized truth that in times of financial and economic crisis, in circumstances of deficit of material and financial resources and limited possibilities for great-scale investments, the best management solution is concentrating efforts and limited funds on development and improvement of education. This is so, because investment in the human factor has the lowest cost price and the highest return on one hand, and on the other - after the end of the crisis and the removal of financial constraints the state or the organization would have well prepared and highly qualified personnel, able to work even more effectively in the new economic, social, political and financial circumstances (2006).

The dynamically changing security environment, European and Euro Atlantic integration of the Republic of Bulgaria and the limited resources the state separates for the security and defence sector determine the military-educational system functioning environment and outline the challenges and requirements for its development and improvement in the present-day circumstances. The state's military-educational system (MES) faces challenges, determined by its exterior and interior functioning environment.

Analysis point that currently the major challenges MES faces are: the reform/transformation going on in AF; putting the state military-educational system in complete compliance with the national and allies' legislation in power; the preparation of soldiers, sergeants and officers, capable to act in multi-national environment; preparation of cadres for the rest of the security sector's structures, for the central administration and for the bodies of territorial and local authorities.

- The reform / transformation going on in the Armed Forces is one of the most important challenges the military-educational system is facing, because there are big tasks in front of the Bulgarian state, connected to restructuring of the Bulgarian Army with a view to fulfilling the responsibilities that result from the NATO and EU membership and their conceptual formulation. The armed forces transformation is conducted on the grounds of the new views of the armies' development and of the new doctrine understanding about the structure and preparation of commanders and personnel. This imposes the necessity of conducting relevant reformations in the system for preparation of military cadres and the military education.

The military-education system reform is determined by the new requirements for the contents and level of preparation of officers in the circumstances of changing the structure, the strength and the tasks (missions) of the Bulgarian armed forces as well as the transformation in the civil higher education. The changing requirements for the future military leaders and managers makes the military education face the challenge for up-dating the contents, the ideology and the didactics of educational process and moving to life-long learning system.

The other major challenge the military-educational system of the country faces appears to be its putting to complete compliance with the operating legislation - NATO strategic doctrines and directives, the Lisbon strategy for establishing European educational space and the European qualification frame, Republic of Bulgaria Defence and Armed Forces Act (RBDAFA), Higher Education Act (HEA), Act for the Development of the Academic Staff, Vocational Education and Training Act (VETA), Medical-Treatment Facilities Act (MTFA) and the Pre-school and School Education Act, acts of the National Assembly regarding the higher military schools statute, the state requirements for acquiring higher education, National Defence Strategy, Strategy for Development of the system for education and qualification of professional military servicemen from the Armed Forces of the Republic of Bulgaria, Programme for Development of the Defence Capabilities of the Armed Forces of the Republic of Bulgaria 2020 and for Determining the Number of the Armed Forces, adopted with Resolution of the National Assembly of 25.11.2015, released in Official Gazette, issue 93, of date 1.12.2015. Plan for the Republic of Bulgaria Armed Forces Development, adopted with Council of Ministers Decree №333/29.12.2010, Plan for the Development of the Republic of Bulgaria Armed Forces 2020, adopted with Council of Ministers Decree №382 of 30.12.2015. Doctrine for Human Resources Management in the Armed Forces, announced with Ministry order № OX-179/06.03.2013, etc.

Republic of Bulgaria NATO and EU membership puts in front of the system for acquiring military education and qualification the challenge of mastering new military culture and the necessity of its continuous improvement and synchronizing with the requirement for raising the role of knowledge and skills of managing personnel at the fulfilment of the tasks in front of the national security and defence system, and mostly in front of the armed forces.

In order to meet the requirements of the continuously changing strategic environment, of the increasing need of professional military education and of the penetrating new technologies, MES is structured and functions in compliance with the state educational and qualification requirements, the national qualification frame, the European directives and NATO directives for organizing and conduction of individual preparation of Armed Forces personnel.

The control is realized through the system of procedures for institutional and programme accreditation by the 
National Evaluation and Accreditation Agency (NEAA) and the annual financial audits of the Court of Auditors. Thus the trend for development of integrated educational model that is under continuous civil control, characteristic of the leading NATO member countries is confirmed. Military education as part of the national higher educational system subordinates its organization, functioning, management and funding to Higher Education Act to a high extent. In this regard, one of the most serious challenges is associated with the accreditation process, through which NEAA recognizes the relevance of activity and education quality in the relevant higher school with the legal and state requirements.

- The challenge MES faces for preparing soldiers, sergeants and officers, who are capable to act in multinational environment is mainly connected to the mastering of new strategic culture, set in the ideology and the NATO allies' documents and connected with the changing security environment, the mastering of new model of strategic and commander's leadership, to managerial skills in managing the resources for defence, the construction and integration of the armed forces and capabilities for successful commanding in wide scope of operations, conducted in peace time, in the circumstances of crisis and military conflict.

Because of the fact that the modern serviceman acts in national, coalition and ally's format, the set of new knowledge is completed by wide range of issues on international security relations, the law, humanitarian studies and psychology as well as mastering the established standard operative procedures. Occupying positions in commanding, headquarters and bodies of NATO requires servicemen to possess specific knowledge, skills and qualities. Our military formations participation in wide scope of Alliance's operations makes the English language training one of the priority tasks, connected to the army modernization and transformation in the course of the following years.

Because of that the Bulgarian servicemen education in the future would be a system of institutional training and qualifying preparation, professional practical experience and individual improvement through lessons from the practice.

- Another challenge the military-educational system faces is that besides preparing cadres for the state defence, it should prepare cadres for the other security structures, for the central administration and for the bodies of territorial and local authorities. The necessity of substantial training of civilians on the issues of national security and defence management turns into public need and is answer to the new requirements for the human resources in the field of security and defence, namely - erudition, competence, communicativeness and mobility.

In order to carry out the missions formulated in the National Defence Strategy the armed forces establish and maintain capabilities for executing the complete scope of tasks in national, ally's and coalition format, which suppose the necessity of possessing appropriate education, specific qualification and skills of the servicemen. This is achieved through maintaining and development of the human factor in the armed forces, and the education and qualification acquiring is basic function of the military-educational system.

Contemporary security environment and the listed challenges as well as the role and mission of MES place the system for military education and qualification in front of continuously growing requirements, the more important of them being as follows: to meet the national educational and qualification requirements, the national qualification frame, the European directives and the NATO directives for organizing and conducting joint (collective) and individual preparation of the armed forces staff; raising the quality and effectiveness in the process of education of cadres for the security and defence sector through applying new interactive methods and technologies of teaching; raising competitiveness through improving the educational process organization and reduction of the training terms; high level of professional competence of the individuals graduating from military-educational institutions; raised requirements towards the preparation of the lecturers theoretically and practically as well as their foreign language preparation; capability to realize mobility of lecturers and students within the military universities, colleges and schools in the countries from NATO.

This, of course, does not exhaust the list of the constantly raising requirements towards MES in the present conditions, which makes it one of the most dynamic and proactive subsystems of the country's security and defence system. Constantly considered should be the intense development of information technologies, which imposes constant changes in the methods and forms of education and training, conducted by the military-educational system through applying new interactive methods and technologies of teaching. The introduction of quality new educational technologies changes the matter of education as a whole. It changes from comparatively short-term military education to life-long education, from specialized it becomes more and more broad. In that regard the priority shouldn't be the mastering of particular samples of new techniques but establishing general military culture for the officers from the various armed forces and types of armies, which to ensure effective communication and inter-action in their future work. Also, more and more increasing is the necessity of systematic enhancing of the qualification of 
IJAEDU- International E-Journal of Advances in Education, Vol. 3, Issue 8, August 2017

lecturers in the field of information and communication technologies and their applying in the military science, etc.

The following major conclusions can be defined:

1. Contemporary strategic security environment is characterized with complexity, unpredictability, dynamic changes and great number of risks and threats for the security on regional and global scale, and the processes and trends in the world, in Europe and in our country are directed towards establishing joint political, economic, social, defence and legal space; globalization of society;s security through building flexible and adequate system for international security; active involvement of NATO and building joint capabilities for solving crisis of any nature, worsening demographic development, reducing the number or armed forces and restraining the expenses for security and defence.

2. The changing security environment makes MES face number of challenges, connected to functioning in the conditions of reform/transformation going on in the armed forces and competitive environment; correspondence of the functioning national and allies' legal base; capabilities to prepare soldiers, sergeants and officers able to act in multi-national environment, and cadres for the other security structures, the central administration and the bodies of territorial and local authorities.

3. In order to meet the listed requirements MES should satisfy many requirements, among the most important are: to comply with the state educational and qualification requirements, the national qualification frame, the European directives and the NATO directives for organizing and conducting joint (collective) and individual preparation of the armed forces staff; raising the quality and effectiveness in the process of education of cadres for the security and defence sector through applying new interactive methods and technologies of teaching and mobility of lecturers and students within the military universities, colleges and schools in the countries from NATO; raised requirements towards the professional competence of the people graduating from military-educational institutions and the lecturers; good foreign language preparation, etc.

\section{CONDITION AND CAPABILITIES OF THE MILITARY-EDUCATIONAL SYSTEM OF THE REPUBLIC OF BULGARIA}

According to the National Defence Strategy and the Doctrine of the Armed Forces of the Republic of Bulgaria one of the key priorities in the development of a modern defence institution is training and preparation of the people in the defence according the present-day standards, as far as the human resources are the most important element of the defence capabilities and basic capital of the armed forces (2016). Military preparation represents quite a purposeful process of selection, training, education, development, evaluation, self-evaluation and self-training for establishing leaders capable of realizing modern, effective and resulting operative-tactic and strategic management.

The system of preparation of human resources for the armed forces is realized as individual military preparation of the staff, collective preparation of the permanently appointed formations and joint preparation within established national or multi-national military formations (2016). Military-educational system ensures individual training of the servicemen in the system for armed forces preparation, defined in the Doctrine of the Armed Forces of the Republic of Bulgaria. That is why individual training is reviewed in details.

Individual preparation includes the training in national and foreign military academies, higher military schools and professional colleges that ensure the initial training and the consecutive professional qualification of servicemen and military leaders. Individual training ensures basic knowledge and skills of servicemen and is one of the main criteria in their career development as well as is base for building ready for action headquarters and formations (2013). The military-educational system gives the necessary education and qualification for successful realization in the military profession as well as in other fields of public life, after discharging the servicemen from the contract-based engagements for service in the armed forces.

According to the Doctrine for management of human resources, the military-educational system of the Republic of Bulgaria id built and develops in compliance with the operating legislation and includes the following structures: military academies, higher military schools, scientific-research institutes and professional colleges. The system is built on historical roots, experience and traditions and maintains highly qualified academic, science, expert and other staff. The military-educational system builds integrated educative-material, documentary and scientific base. It maintains and improves information and educative fund, rules, processes and procedures, organization and technology of training and other assets that ensure high quality of the acquired education and qualification, in compliance with the state educational and qualification requirements in the Republic of Bulgaria, the National qualification frame, the European directives and the NATO directives. 
The mission of the military-educational system is to conduct training of military servicemen and civilians for acquiring education, qualification, competences and to form value orientations and mind-set, physical and psychic qualities that comply with the needs of the armed forces for building the necessary defence capabilities (2013).

The main principles of military-educational system building and functioning are:

- Conformity with the functioning legislation;

- Combining the uniform governance with academic autonomy and self-governing;

- Innovation and binding to the modern practice;

- Education relevance, according the cadre's declarers;

- Unity of training and education;

- System, succession and continuity between the educational stages and qualification levels, modules and stages of preparation;

- Conformity to national and allies' doctrines and standards;

- Efficaciousness and economic effectivity;

- Openness, mobility and competitiveness;

- Market orientation.

The listed principles are directed towards building a modern military-educational system, relevant to the strategic security environment and the dynamically changing conditions in the NATO and EU countries.

The following main strategic goals ensue from the compliance with the mission and the principles of militaryeducational system's construction and functioning (2006):

- Conduction of training in compliance with the missions and tasks of the armed forces, country's legislation, NATO requirements, the European standards and the model for servicemen's official development;

- Transition to wide profiled module training, based on the system of educational credits accumulation and transfer and on lessons from the practice;

- Building a modern educational-material base grounded on the information technologies with web-based training, simulators and trainers;

- Introduction of modern technologies of lecturing and training;

- Infrastructure renewal and putting in in compliance with the NATO standards' requirements;

- Raising the qualification of scientific-lecturing and scientific-researching staff in compliance with the armed forces' missions and tasks and introduction of new criteria for selection and development;

- Improvement of the system for studying the trainees realization and taking of managerial decisions for changes in the training documentation, relevant to the needs;

- Establishing centers for studying home and foreign experience;

- Conduction of monitoring regarding the results from the training.

The above goals are laid down in the Strategy for development of the education and qualification system of the professional armed forces servicemen in the Republic of Bulgaria and we consider them being objective, purposeful and outline the main directions in the MES development in the following several years.

Main tasks of MES are (2006):

- Preparation of uniform qualification frames for officer and sergeant (petty-officer for the Naval Forces), on which base the qualification features of the various specialties to be elaborated;

- To complete a review of the training documentation for training of officers at strategic, operative and tactic 
level and of sergeants (petty-officer for the Naval Forces) for conforming to the qualification frames and the system of credits accumulation and transfer;

- Synchronizing the specialties and specializations on which training at tactic and operative level is realized with the table of specialties kept on record;

- To complete the building of academic networks in the military schools;

- To synchronize the system for scientific - lecturing and scientific-researching staff evaluation with the requirements of Republic of Bulgaria Defence and Armed Forces Act (RBDAFA) and Higher Education Act (HEA);

- Improving the system for training process evaluation in interior and foreign aspect.

Main elements of the military-educational system are:

- Staff - academic staff, the trainees, administrative and servicing personnel;

- Training-material base - material resources, used for he training process realization;

- Training organization - organizational structure, responsibilities and interaction between the structures conducting the training and the organization related to that process;

- Training technology - forms of training, requirements, training methods, system for training quality management.

These elements are functionally connected for realizing the training - educational, administrative-managerial, social-living and financial activity for individual preparation of cadres needed for the armed forces (2006).

We can summarize that the military-educational system is complex, adaptive and flexible system that develops in unity, with mutual completing and without duplicating the civil education system in the Republic of Bulgaria. It is meant to correspond to the needs of the Bulgarian armed forces for training of servicemen and civilians by the Ministry of Defence and other administrations as well as of foreign citizens on the issues of security, defence policy and military science. MES's characteristic feature is the wide scope of trainees'categories - cadets, post-graduate students, listeners and doctorate candidates.

According to Republic of Bulgaria Defence and Armed Forces Act (RBDAFA), the military-educational system is structured by: bodies of management at strategic level (from the Ministry of Defence), military academies - Georgi Stoykov Rakovski National Defence College, Military Medical Academy and higher military schools - Vasil Levski National Military University and Nikola Vaptsarov Naval Academy. Beside them, the Institute of Defence also belongs to the military-educational system. It is a scientific-research, research-construction and expert-technical section to the Minister of Defence. The Institute of Defence is established with Council of Ministers' Decree №140/04.06.2009 and is successor of the rich traditions of the former military-scientific organizations - Military scientific-technical institute, Military scientific-research institute, Institute for perspective defence studies, Tests and Control Measuring of Armoury, Equipment and Properties Executive Agency, Apparatus of the General constructor of the Complex automated system and the systems C4I of the Ministry of Defence.

We will review in more detail the condition and possibilities of Georgi Stoykov Rakovski National Defence College, Vasil Levski National Military University and Nikola Vaptsarov Higher Naval School for individual training, for qualification raising and for pre - qualification of the different categories of servicemen, civil officers and civilians for the needs of security and defence.

The military academy and the higher military schools are educational institutions with more than 135 years of history, experience and traditions and are basic elements of the Bulgarian military-educational system in organisational and educational aspect, where specialized training is realized, qualification and professional preparation is acquired by the servicemen and the civil officers of the Ministry of Defence as well as by officers from other ministries, administrations and civilians (2013) Military academies and the higher military schools realize specialized education for acquiring educational-qualification and educational and scientific degree, training for qualification raising and for professional preparation of cadres in the security and defence sector. Furthermore, they conduct training of civilians such as university students, doctoral candidates and post-graduate students, for acquiring educational-qualification degree of "Bachelor” and/or "Master” and educational and scientific degree of "Doctor” in accredited professional subjects and specialities. Acquiring higher military education by the officers' staff is realized for tactic, operative and strategic level, where additional post-graduate qualification is acquired between each one of them depending on the requirements 
for occupying a particular position (2013) The Military Academy and the higher military schools are established with resolution of the National Assembly, the professional sergeants' colleges - with Minister of Education and Science's order after Minister of Defence's suggestion, and the training centers - with Minister of Defence's order. The Military Academy and the higher military schools apply the regulations of the Higher Education Act and the Republic of Bulgaria Academic Staff Development Act, and the professional colleges - the Vocational Education and Training Act and the Pre-school and School Education Act. Professional colleges for preparation of sergeants (petty-officers) carry out training for acquiring fourth degree of professional qualification by sergeants (petty-officers) under the Vocational Education and Training Act under the order of Republic of Bulgaria Defence and Armed Forces Act (RBDAFA) (2013) Training centers for preparation of soldiers (sailors) are established with the Minister of Defence's order, which sets their statute, organization and assets (2013). The uniform management of military education and qualification and of the scientific activity is realized by the Minister of Defence in compliance with his given powers, and the immediate management of MES is realized by the deputy Minister of Defence. The connections with other Bulgarian Army structures is realized through the Chief of defence. MES realizes contacts with Ministry of Defence structures and foreign organizations through the deputy Minister of Defence responsible for its management (2013).

According to the Doctrine for human resources management, the acquisition of higher education for tactic level is realized in the higher military schools and in foreign military academies and schools. The acquired military education and the periods of training abroad are recognized on conditions and under order, defined by an act of the Council of Ministers, and the qualification is equalized by the Minister of defence's order (2013).

The higher military schools train Bulgarian and foreign civilians with secondary education as cadets for acquisition of educational-qualification degree and professional qualification „officer for tactic level of management" and specialized preparation for service in the armed forces according the state requirements. The conditions and order for admittance of trainees are defined by regulation and annual orders of the Minister of Defence and the chiefs of the higher military schools.

The acquisition of professional qualification "officer for tactic level of management” is realized in the higher military schools through (2013):

- Training of cadets for acquiring educational-qualification degree (EQD) of „Bachelor” in specialties from professional profile "Military Science” and in civil specialties in compliance with established qualification characteristics and uniform curriculum;

- Training of cadets for acquiring educational-qualification degree of „Bachelor in ...” in specialties from professional profile "Military Science" without training in civil specialty in compliance with established qualification characteristics and uniform curriculum;

- Training of civilians, civil officers and servicemen with military title from „private soldier” to „officer candidate", who have graduated higher school, after curriculum for acquiring qualification in Military Science and adopting first officer rank after curriculum for acquiring qualification in Military Sciences and adoption of first officer rank for appointing to a position in the armed forces.

The cadets, who have completed the training in all subjects included in the curriculum and successfully took the relevant exams, are awarded higher education diploma in educational-qualification degree „Bachelor” in the relevant specialties with professional qualification "officer for tactic level of management".

The training of civilians and civil officers that have diplomas for higher education in specialties, in which no training is realized in the higher military school (medical men, meteorologists, financiers, jurists, topo geodesists, conductors and others), is realized according curriculum for acquisition of qualification in Military Sciences, adoption of first officer rank and appointing to a position in the armed forces in the scope of career field „professional” (2013)

The training of servicemen that have diplomas for higher education and possess military rank from „private soldier" to "officer candidate" after curriculum for acquiring qualification in Military Sciences, adoption of first officer rank and appointing to a position in the armed forces is realized only for honoured after command order servicemen with proven qualities, participation in missions, foreign language preparation and classed for the relevant training (2013). 
Since 01.06.2010 the higher military schools are structured as follows:

\section{Vasil Levski National Military University:}

- All-army Faculty - town of Veliko Tarnovo;

- Aviation Faculty - town of Dolna mitropoliya;

- Artillery, Air defence and CIS Faculty - town of Shumen;

- Center for professional and continuing education;

- Center for post-graduate qualification;

- Center for distance training;

- Center for preparation of cadres for peace-keeping operations and experience study;

- Institute for Research and Innovation;

- Language and Physical Training Department

- Foreign Language Training Department;

- Professional Sergeants' College

\section{Nikola Vaptsarov Higher Naval School:}

- Navigation Faculty;

- Engineer Faculty;

- Post-graduate Qualification Department;

- Professional Sergeants' College;

- Military Preparation Center.

The preparation of cadets in the training of module "Tactic Level" is separated into academic, military, leader's, foreign language and physical preparation (2006).

The academic preparation supports and further develops the military preparation and includes subjects for acquiring of educational-qualification degree in civil specialties.

The military preparation includes primary military preparation with duration of up to 4 months, all-army military preparation with duration up to 6 months and special military preparation with duration up to 2 years.

Leader's preparation is held in regular lecture time on a module principle, with theoretic and practical lessons throughout the whole course of training.

Foreign language preparation finishes with exam for mandatory covering of level 1-1-1-1 after the requirements of the NATO standard SATANG 6001.

Physical preparation is held throughout the whole course of training regularly and in extra-curricular time, where each trainee is mandatory ensured with three times a week possibilities for sports training. Physical preparation is evaluated once a year and finishes with state exam.

Academic and professional military preparation of cadets shapes them as officers for managing a military unit (platoon, company and others equalized to it), for managing the war use of the weapons and the technical means as well as for observing the obligations of duty officers. The preparation during the period of training takes place in strict methodical consequence, with continuous control and evaluation of knowledge and skills. The training finishes with state exams. The commander's probations, flying preparation and navigation practice are held in the formations of the relevant type of armed forces. There the cadets are rendered acquisition of solid professional skills and habits (2006).

Characteristic feature of the military-educational system is that in contrast to the national educational system, the training for acquiring educational-qualification degree "Bachelor" in the professional field of Military Sciences ensures narrower specialization and extension of preparation in compliance with the acquired military specialty corresponding to the type of army. This is defined by the fact that the graduates of the National Military School and the Higher Naval School occupy position at tactic level in the relevant specialty kept on record, which requires knowledge of the material part and specialized tactic knowledge and skills. 


\section{SYSTEM FOR TRAINING OF OFFICERS AND CIVIL OFFICERS AT OPERATIVE AND STRATEGIC LEVEL}

Georgi Stoykov Rakovski Military Academy conducts training of officers at operative and strategic level.

Since 01.06.2010 the main departments of the academy are:

- National Security and Defence Faculty;

- Command-Staff Faculty;

- Linguistic Training Department;

- Institute for Perspective Defence Research.

Georgi Stoykov Rakovski Military Academy as well as foreign military academies and colleges conduct acquisition of higher military education and qualification for occupying positions at operative level. The education acquired in other countries and the training periods are recognized at conditions and under order, defined with an act of the Council of Ministers, and the qualification is equalized to the qualification acquired in the military academy with Minister of Defence's order (2013).

The Military Academy conducts training of Bulgarian and foreign servicemen and civilians, who have higher education diplomas, for acquiring educational-qualification degree of "Master"in accredited specialties of professional fields of Military Sciences and National Security and acquiring educational and scientific degree of "Doctor"in accredited professional fields and specialties.

The training under a curriculum for acquiring higher education diploma in specialties from the professional field of Military Sciences in educational-qualification degree of "Master"is realized in compliance with state requirements ordinance, adopted with an act of the Council of Ministers.

The training under a curriculum for acquiring higher education diploma in specialties from the professional field of National Security in educational-qualification degree of "Master"is realized in compliance with curricula, approved by the Minister of defence, coordinated with the Minister of Education, Youth and Science.

The training under a curriculum for acquiring higher education diploma in specialties from the professional field of Military Sciences is characterized by inter-disciplinary and wide range preparation, which is due to the fact that the graduates of Georgi Stoykov Rakovski Military Academy occupy positions at operative level, which require wide theoretical knowledge and practical skills. This training is organized with the goal to ensure the necessary knowledge, leader's skills and habits for work in national and multi-national operative and tactic headquarters. The training is oriented towards officers and civilians from the armed forces, from the other ministries and administrations, the central and local administration, experts from various fields of economic and administrative life (2013).

The training in the Operative Level module is realized in the Command-Staff Faculty of Georgi Stoykov Rakovski Military Academy for acquiring educational-qualification degree "Master" in specialties of professional profile Military Sciences in the field of higher education in Security and Defence. The training provides preparation and extending other preparation in the field of military sciences in compliance with the acquired speciality. Officers' preparation at operative level is separated into military, leadership, linguistic and physical preparation (2006).

Military preparation. Training's main goal is to provide the trainees with preparation in the fields of theory of war, strategy, operative art and tactics as well as skills to organize and conduct military actions and operations in various circumstances and with various aims. The following courses (subjects) are studied in the module: theory of war, strategy; theory and practice of operative art and tactics; theory and practice of military operations different from war, future operations.

Military special preparation. The module's goal is to extend the trainees' knowledge and skills for activities that are specific for the specialty. The studied subjects are defined by the particular department after coordinating them with the military schools' curricula and with the courses.

Leadership preparation. The goal is to form in the trainees managing skills that correspond to the contemporary requirements. The following courses are studied in that block: communication, leadership, command and management.

Linguistic preparation. Officers' linguistic preparation is conducted in order to achieve knowing English 
language to an extent that allows carrying conversation on professional and specific topics, using English language literature on the specialty and drawing necessary for their activity documents in interest of the conduction of activities within NATO. The training finishes with test for English language mastering under the NATO standard of STANAG6001 at a level not lower than 2-2-2-2.

The training in the master specialty Strategic Management of Defence and the Armed Forces is a higher stage of preparation of the officers from the armed forces and it gives the necessary professional qualification for occupying positions that require higher military knowledge. Senior officers that possess educational-qualification degree Master in professional profile Military Sciences awarded in higher schools in the country or abroad participate in the programme (2013).

The training in module Strategic Level is held in National Security and Defence Faculty of Georgi Stoykov Rakovski Military Academy for acquiring educational-qualification degree Master in specialty Defence and Armed Forces Strategic Management from professional professional profile Military Sciences in the higher education field Security and Defence (2006).

The preparation of officers at strategic level is separated into military and leadership preparation.

The military preparation includes studying the following subjects: theory of national and international security; theory and practice of management in crisis, military strategy and operative art in joint and multi-national operations; theory and practice of defence and armed forces management at strategic level.

The Leadership preparation is held in the regular lecture hours on a module principle with theoretical and practical lessons in strategic leadership throughout the entire training course.

The graduate may occupy high command positions after successful preparation completion and depending on his professional experience.

\section{SERVICEMEN AND CIVIL OFFICERS' QUALIFICATION EXTENSION AND PRE- QUALIFICATION}

The post-graduate specialization in Georgi Stoykov Rakovski Military Academy, Vasil Levski National Military University and Nikola Vaptsarov Higher Naval School is structured in a system of courses with various duration and is annually planned depending on the needs of the armed forces and of the Ministry of Defence's structures (2013).

Qualification acquisition is training of servicemen and civil officers in a profession or part of a profession that includes combination of professional competences and necessary for their formation general educational knowledge and skills. Professional competences are formed on the grounds of acquired knowledge and skills that contribute to manifesting inattentiveness, to team work and to quality exercising of certain profession according the state educational requirements for acquiring qualification in a profession.

Qualification extension is training for maintaining and improving professional knowledge and skills of servicemen and civil officers during their service entire period in compliance with their job description, and the current and future armed forces tasks, the military science achievements and the development of armaments and fighting equipment (2013).

The qualification is acquired, extended and improved through training in courses for job and additional (target and linguistic) qualifications. Job qualification is training for mastering knowledge and skills that are necessary for occupying particular positions. Additional qualification is training for mastering additional knowledge and skills necessary in the process of professional activity.

Job qualification continues up to 16 school weeks for getting additional knowledge and skills necessary for occupying position, for ensuring fast and effective acquaintance with the work and position realization (2006).

Target qualification is in the form of seminars and courses with duration from one to four weeks. It is conducted for mastering specific knowledge and skills on issues no training in the master programme is conducted on, or ones imposed by the completion of specific missions and tasks, changes in staff, job descriptions, introduction of new fighting equipment, new doctrinal and military documents, etc. Target qualification is not connected with the trainees' positions but with the nature of their activity (2006).

The linguistic post-graduate qualification is held at levels of duration varying from 8 to 14 school weeks. Each next level training officers, who possess document for completed previous level (2006).

The training in courses for acquiring and extending the qualification and for pre-qualification of servicemen and civil officers from the armed forces is carried under order and conditions, regulated with Ordinance № H19/25.05.2010 of the Minister of Defence, and the civil officers training is held in compliance with the orders 
of the Labour Code. The courses for acquiring and extending of qualification and for pre-qualification of servicemen and civil officers are announced annually in the Courses Register with order of the Minister of Defence. The administrative and training documentation of courses are elaborated by the training organizations after announcers' suggestion and are approved by the Minister of Defence (2013).

The forms of training in courses for acquisition and extension of qualification and pre-qualification are fulltime, extramural and distant.

Analysing the contemporary status of Bulgarian military-educational system, there are single problems and discrepancies seen that impede the system's functioning. The resource provision is the part of the entire organization of activity in the Military Academy, the National Military University and Higher Naval School that creates the necessary material prerequisites for normal conduction of their everyday activity. The complex development of the tree basic elements of resource provision - human resources, financial and material provision and infrastructure are the necessary requisites for achieving its final goal.

In negative aspect, analysing the results from the activity of Georgi Stoykov Rakovski Military Academy as well as of the higher military schools in the recent years, it is seen that they face common for all as well as specific difficulties that impede the training process additionally and create preconditions for reducing the quality of training. Some of them are: presence of great number of vacant lecturers' positions; ageing lecturers' staff, particularly concerning the lecturers with academic rank; lack of motivating system for the officers from the headquarters and the armed forces formations to realize themselves as lecturers; insufficient and ineffective usage of instructors in the training process; execution of unusual obligations by the lecturers staff and the trainees; insufficient financial providing for modernization of training-material base and infrastructure; limited possibilities for practical training of cadets concerning material issues, etc.

The following conclusions can be made after analysing the overall condition and possibilities of militaryeducational system:

1. Military-educational system of the Republic of Bulgaria is built, functions and develops in compliance with the legislation in power with the following structures: military academies; higher military schools; scientific and research institutes and professional colleges that include elements such as lecturers staff, training and material base, organization and technology of training.

2. In compliance with its mission MES, as a whole, performs its tasks successfully concerning conduction of training of all categories of servicemen (officers, sergeants and soldiers) and civil officers from the Ministry of Defence as well as of officers from other ministries and administrations, central and local administration, for acquisition of education, qualification, competencies and shaping of qualities that correspond to the needs of armed forces for building the relevant defense capabilities. The acquisition of higher education by the officers' staff is realized for tactic, operative and strategic level in professional profile Military Sciences. Training in professional profile National Security at operative and strategic level is conducted for civilians. All of them are offered also training for educational and scientific degree Doctor in accredited professional professional profiles and specialties, and they can also acquire job and additional post-graduate qualification depending on the requirements for occupying particular position.

3. Under the conditions of dynamically changing security environment, under the influence of the processes originating from NATO and EU regarding the education and training and the limited resources separated by the state for the security and defence sector, MES faces new requirements that outline the directions for its development and improvement in the contemporary conditions. At the same time there are number of discrepancies and problems for solving in from of MES, namely: over-normative burdening of the lecturers' staff, ageing lecturers' staff with academic rank, lack of motivation for new lecturers, limited financial resources for maintenance of educational and material base and infrastructure, etc.

\section{DIRECTIONS FOR IMPROVEMENT OF THE MILITARY-EDUCATIONAL SYSTEM AND ITS CONTRIBUTION FOR STRENGTHENING NATIONAL SECURITY AND THE DEFENCE OF THE COUNTRY}

Analysing the main military-educational system elements' condition (personnel, educational and material base, organization and technology of education) and considering the necessity of complete military education harmonizing with the requirements of the European directives and NATO directives, we can outline the main directions and possibilities for improving of the Bulgarian military-educational system in conceptual, organizational and technological aspect.

\section{Conceptual improvement of military-educational system}

Republic of Bulgaria's membership in NATO and the EU brings the necessity for medium turn plan for entire 
harmonization of military education with the military education provided by similar colleges and academies in the allied countries, for enhancing the competitiveness of the system for military education and qualification at operative and strategic level. In pursuance of the signed international treaties and the adopted national strategic documents, with Minister of defence's order № OX-249/18.04.2011 organization for development of MES is established in compliance with the White Book of Defence and Armed Forces and the Plan for Republic of Bulgaria Armed Forces development to 2020. It is planned that the system for acquiring military education and qualification to be up-dated in compliance with NATO strategic doctrines and directives from the Lisbon strategy for building European education space and European qualification frame, and the requirements for the higher military education and professional training connected to them.

The activity on development and setting the system for acquiring of military education and qualification in compliance with the Alliance's strategic documents is conducted in the following directions:

1. Further improvement of military-educational system according national and European legislation and NATO directives for achieving quality individual preparation of the armed forces personnel;

2. Acquisition of knowledge and enhancing the skills aiming building necessary skills and competences for achieving conformability with the NATO member countries in participation in multi-national missions, trainings and operations;

3. Realization of close and continuous relation between educational and training institutions and the users/requester of cadres;

4. Better use of information technologies based on WEB-training, simulators and trainers and introduction of modern technologies of lecturing and learning;

5. Ensuring the quality of higher education and professional training in qualification courses;

6. Setting and bounding the national qualification system with the European qualification frame (EQF);

7. Establishment of new and change of the existing courses for acquisition and extension of qualification aiming ensuring the career development of sergeants' staff;

8. All certificates fro acquired qualification, diplomas and other type of documents issued by the higher military schools to clearly point grounding on the relevant EQF level;

9. Improvement of sergeants' staff preparation in the professional sergeants'(petty officers') colleges as well as through creating opportunities for adopting the military rank Junior Sergeant after completing training in training center of the relevant type of armed force;

10. Ensuring training in the course of the entire period of military service and use of the possibilities of information and communication technologies for access to training at any time;

11. Increase of the investments in military education and qualification and efforts for up-dating and modernizing of material and training base (2011c).

Great part of the planned particular actions under the pointed directions for MES improvement are executed and the process continues according to plan, while preparedness for immediate reaction is maintained for in the European and NATO directives. This way the legislation for the Bulgarian military-educational system functioning is synchronized with the national and the European legislation and the NATO directives, by which national programmes for education and operative preparation are equalized with the Alliance's standards as well as the quality requirements and criteria for the higher military education and professional training.

Review and up-date of the 2006 Strategy for development of the system for Republic of Bulgaria Armed Forces education and qualification of professional servicemen is necessary, considering the occurred changes in conceptual, doctrinal, organizational and terminological aspect.

Beside that the already mentioned problems with the ageing lecturers with academic rank, the presence of great number of vacant lecturers' positions and the lack of motivation system for the officers from the headquarters and armed forces to become lecturers, could be solved by:

- Elaboration of new conceptual documents or making changes in the existing ones to turn them into powerful tool, with which the status quo to be changed. Only this would ensure independence and higher autonomy of military schools and academies, similar to the ones in the rest NATO and EU countries. The military education system in its contemporary shape is too centralized, distant to the troops and headquarters life and not always flexible and adequate to the changing circumstances;

- Change in some of the strategic organizational regulating documents - Defence and Armed Forces Act 
(DAFA), Regulations for Enforcing DAFA, Strategy for development of Republic of Bulgaria professional servicemen and armed forces education and qualification system etc., to give possibilities for better financial conditions and to guarantee the career development of the officer-lecturer. Beside that, to ensure binding of officers lecturers' with the practical execution of tasks in the headquarters and the troops through probations, participation in trainings and rotation;

- In order the position of a lecturer in the higher military school to gain attractiveness, the positions there should be equal or higher that the similar ones ones in the forces or the relevant headquarters. There is no other known and successful motive for attracting to the lecturers' job, except the higher position and the better payment.

- 2-3 years of practice at an academic position to be set as mandatory condition at the enrolling on particular positions at operative and strategic level in the Ministry of Defence.

\section{Military-educational system organizational improvement}

MES organizational improvement includes the elements personnel and training organization, as far as this process concerns the inter-relation between the academic staff, the trainees, the administrative and servicing staff of the military-educational entities, but also influences the organizational structure, the responsibilities and inter-action between the institutions that conduct the training, and the organizations users and requesters of cadres.

- The armed forces structure review and the adopted by the National Assembly White Book for the Defence and the Armed Forces are completed until 2014, and the adopted Plan for the Armed Forces Development to 2020 makes analysis and defines the relevant activities for the change implementation.

In pursuance of the Plan for the Republic of Bulgaria Armed Forces Development, section Education, Science and Training is planned the higher military schools to maintain their institutional and programme accreditation, to optimize their structures through mainly reduction of the administrative and provisioning staff and to create new possibilities for maximum scope of the candidates for training in them (2015a).

In order the higher military schools to be able to realize their priorities regarding possibilities developing the existing acquiring new ones, the following activities are carried: military higher schools structure inside optimization aiming administrative and provisioning staff reduction; up-date of the requirements for acquiring educational - qualification degree Bachelor and Master in the specialties from Military Science professional profile; elaboration of new training documentation for cadets and civilians training with term of training 3 years and 1,5 years; transfer to 14-month training of listeners - full-time form; better use of the possibilities for integration with other higher schools (Erasmus and Military Erasmus); setting higher criteria at the selection of scientific cadres -servicemen and civilians: proved professional qualities, skillfulness and foreign language at a level not lower than 2-2-2-2 after STANAG, practical and military experience from participation in Alliance's and coalition missions and operations (only for the servicemen); opening position Instructor for military-applied, professional and practical training in the military academies and the higher military schools aiming close binding of cadets' and listeners' training and practical preparation (2015a).

Great part of the described activities is completed, and as for the position Instructor, the task is fulfilled, but as it was already mentioned, the effectivity of that institution is still too low. The reason is that instead of the officers returned from international positions to share their experience in the Military Academy, the National Military University or the Higher Naval School for 1-2 years, they are sent to Staff 916 in the Ministry of Defence, and these positions are occupied by officers with no experience like that.

- The other direction for MES organizational improvement is an inter-disciplinary joint training of the officer (employee) from the security and defence system at strategic and operative level as well as education that allows him growing in the national hierarchy and in the international organizations.

The joint training and preparation of military and civil experts for work at the various managerial levels gets more and more significant in the public space. The training at this level (of jointly military and civil experts) is conducted by selected lecturers with attracting experts from ministries, administrations and other civil structures, in groups of not more than 14-16 people, allowing substantial discussions and using of the most modern means of illustrating and analysis. Beside that, joint training of officers from the various types of armed forces is of crucial significance for the transformation in the military education and for achieving the goals of the operative compatibility. Education in joint programmes has a significant contribution for establishing new military culture and mentality and guarantees maximum use of specific capabilities for achieving quick and decisive effect in operations. 
On the other hand, joint training is one of the main directions in the process of NATO military capabilities transformation. This requires coordination and uniting individual and collective training and NATO operative preparation as well as equalizing national programmes for training and operative preparation with the Alliance's standards. That's why a key approach in the realization of the policy in the field of military education and qualification should be improvement of the joint nature of training at strategic level and its distribution and establishing at operative and tactic level.

- Crucially significant for the MES organizational improvement and training quality raising is the effective involvement of the users/requesters of cadres, i.e. Ministry of Defence, Staff of Defence and the various types of armed forces in the elaboration of the qualification characteristics as well as the extending of cooperation between the Military Academy and the higher military schools, the Bulgarian Academy of Sciences, the universities and other institutions and higher specialized schools in Bulgaria, and particularly the international cooperation. The active inclusion and participation in the Military Erasmus initiative contributes more and more to bringing closer the standards in the future officers preparation in the military schools of the European Union member countries.

- Favourable opportunity for each educational institution to raise the training quality is planning organization improvement, training process conduction and reporting. This is a combination of particular activities with view to the specifics of each higher military school and there are particular bodies and working methodics at each place.

- Beside that, organizational improvement could be very useful for overcoming the common problem with the insufficient financial and material resources for ensuring the activity of the Military Academy, the National Military University and the Higher Naval School, where the expenses are limited and additional income is ensured in the budget of the relevant school through resourceful organizational solutions. For example planning, programming and budget-making processes optimization; financial ensuring of priorities; own income increase through organizing the conduction of training and qualification courses, participation in scientific projects and energy effectiveness projects; close collaboration with the types of armed forces and the business on joint projects, etc.

- Over-normative burden of lecturers' staff could also be relieved through organizational measures such as purposeful planning, combining of number of trainee groups in bigger flows in same subjects, electronic examining, etc.

Generally, these directions do not exhaust all possibilities for optimization of activity but give a path for overcoming the difficulties and opportunity for MES to meet more fully the higher requirements and challenges that result from the security environment.

\section{Military-educational system technological improvement}

MES technological improvement includes the elements of personnel, training and material base and technology of training, as far as this process requires academic staff preparation enhancing, training and material base improvement and applying modern forms and methods of training as well as training quality management system.

In order to be adequate with the wide use of information technologies in the field of education, MES should: first, provide good preparation to the academic staff as well as to the trainees and to the CIS (Computer and Information Systems) exploitation and maintenance team, training equipment simulators; second - to provide modern training and material base, equipped with quality techniques and licensed software products and software; and third - to ensure strict observing of the requirements of Classified Information Protection Act, Personal Data Act and other regulatory documents in the work process.

- The high requirements towards the military education and qualification imposed the wide introduction of information technologies, modeling and simulations and modern web-based training in education. Modeling and simulations virtual world is the modern military education and military scientific research environment. New national and allies' missions and tasks require preparation for holding operations in any geographic and climate conditions, which could be virtually reproduced only through modeling and simulations.

- New realities require from MES enhancing quality and effectiveness in the process of training cadres for the security and defence sector through applying new interactive lecturing methods and technologies, impose higher requirements towards the professional competencies of graduates of military-educational institutions and towards the lecturers' preparation for better use of information technologies, based on webtraining, simulators and training equipment and introduction of modern technologies of lecturing and learning 
as well as ensuring access to training at any time.

- Applying the newest achievements of science, technics and technologies in the field of military education and qualification leads to achieving optimization of the element technology of training and considerable modernization of the training process itself in several directions: higher effectiveness and efficacy, embracing bigger group of trainees, more efficient training time and training at any time, distant training and training under individual plan, joint/cooperated training with other academies, schools and institutions in real time, enhancing the overall academic staff preparation, etc. This contributes more and more to getting closer to the standards of preparation of future officers in the military schools of the NATO and European Union member countries and to achieving high extent of compatibility.

Summarizing the information on the actual condition with the main profiles and possibilities for improvement of the Bulgarian military-educational system, the following conclusions could be made:

1. The impact of the processes taking place in NATO and the European Union regarding education and training, are the main favourable factor for the future Republic of Bulgaria military-educational system's development and improvement. All this imposes continuous improvement of the system for military education and qualification in at least three aspects - organizational, technological and conceptual.

2. The main issues in the military-educational system's conceptual improvement are legislation's base change and maintenance in compliance with the national and European legislation and with the NATO directives and creating favourable conditions for attracting young officers to the lecturers' job and in organizational aspect - higher military schools structures' interior optimization; administrative and providing staff reduction; training forms and terms change; extending the joint training at strategic and operative level; close interaction and cooperation with the types of armed forces on joint projects; international cooperation and experience exchange with scientific-educational and scientific-research institutes in the country, etc..

3. The opportunities for technological improvement include extended introduction of information technologies, modelling and simulations, building of a new information environment of training and applying new interactive methods and technologies of real-time distant lecturing and serviceman and civil officers lifelong training.

\section{CONCLUSION}

1. The strategic environment changes in the beginning of the $21^{\text {st }}$ century, the county's equal-rights membership in NATO and the EU, the changes in the regulatory acts regarding collective security and defence, the transition to professional army, the building of armed forces new structure, personnel, armaments and technics reduction, Bulgarian Army forces' participation in international missions and multinational headquarters imposed new requirements, challenges and directions for development and improvement of military-educational system for building of efficient armed forces adequate to the dynamically changing circumstances in the security environment.

2. Republic of Bulgaria military-educational system is built on historical roots, experience and traditions, has highly qualified academic, scientific and expert staff, developed training and material, documentary and scientific base, maintenance and improvement of information and training fund, rules, processes and procedures, organization and technology of training and other assets that ensure at the moment high quality of the acquired education and qualification, in compliance with the state educational and qualification requirements, the national qualification frame, the European and NATO directives.

3. In the circumstances of dynamically changing environment, the complicated processes taking place in NATO and the EU, regarding education and training, and the limited resources, separated for the security and defence sector by the state, MES faces new requirements thus outline the directions from its development and improvement in the contemporary conditions. Beside that, MES has number of discrepancy and problems to solve, namely: Over-normative burden of lecturers' staff, ageing lecturers with academic rank, lack of motivation for new lecturers, limited financial resources for maintenance and modernization of training and material base and infrastructure.

4. NATO and the EU are favourable factor for the future development and improvement of the Republic of Bulgaria military-educational system. But that imposes continuous improvement of military education and qualification system in three directions - organizational, technological and conceptual. In conceptual aspect it imposes setting and maintenance of legislation in compliance with the national and European legislation and the NATO directives, for attracting young and perspective officers for lecturers, and in organizational - structures optimization; administrative and providing staff reduction; training forms and term change; joint training; successful financial management; collaboration and cooperation with the types of 
armed forces; international cooperation and experience exchange inside the country, etc. The possibilities for technological improvement include extended introduction of information technologies, modeling and simulations and application of new interactive methods and technologies of real-time distant lecturing and servicemen and civil officers life-long training.

5. In the changed security environment, the system for human resources preparation for the armed forces (individual and collective) includes activities and processes that require time and resources for training of servicemen for achieving certain standards. Regardless of where and at what level the serviceman prepares, he has to be provided purposeful, realistic, challenging and resource-ensured preparation. These requirements towards the military-educational system are the grounds, necessary for building skillful and situation-adaptive servicemen, headquarters and forces.

The condition of MES in the time of the research is in objective connection and dependence on the security environment in the country and on the processes taking place in NATO and the EU regarding education and training. The systems functions in the conditions of insufficient financial, material and human resources for execution of its mission and tasks and develops for setting in full compliance with the state educational and qualification requirements, the national qualification frame and the European and NATO directives.

Military-educational system has established national strategic documents for its future development in medium term and has potential to perform the planed actions for improvement and for contribution to the enhancing of national security and country's defence.

The Bulgarian military education and qualification synchronizing with the ones in the EU and NATO countries in conceptual, organizational and technological aspect is of primer significance for the transformation of military education and for achieving the goals on operative compatibility between the armed forces.

\section{REFERENCE LIST}

Republic of Bulgaria Strategy for National Security, published in State Gazette, issue19 of 08.03.2011 (2011a)

National Defence Strategy, Ministry of Defence, S. (2016).

Doctrine for Republic of Bulgaria Armed Forces Preparation, Republic of Bulgaria Armed Forces National Publication HП - 7, Ministry of Defence, S., (2012a).

White Book for Republic of Bulgaria Defence and Armed Forces, Ministry of Defence, S., (2010a).

Plan for the Development of the Republic of Bulgaria Armed Forces 2020, adopted with Council of Ministers Decree №382 of 30.12.2015. (2015a)

Strategy for Development of the System for Education and Qualification of Professional Military servicemen from the Armed Forces of the Republic of Bulgaria, Military Publishing House, S., (2006).

Doctrine for Human Resources Management in the Armed Forces, announced with ministry order № OX179/06.03.2013. (2013).

Strategy for Education and Science in the Security and Defence System - collection, Military Academy - BA, $S, 2011 .(2011 b)$

Strategy for Development of Georgi Stoykov Rakovski Military Academy in the period 2007-2015, Ministry of Defence, S., (2007).

Regulation for Georgi Stoykov Rakovski Military Academy Organization and Activity, published in State Gazette, issue 47 of May $18^{\text {th }}$ (2001)

Order of the Minister of defence of the Republic of Bulgaria № OX-249/18.04.2011 regarding „Performing the Review of the Armed Forces Structure and the White Book for the Defence and the Armed Forces on the issues for the military education and qualification". (2011c)

Republic of Bulgaria Defence and Armed Forces Act, published in State Gazette, issue 35 of 12.05.2009. (2009)

Higher Education Act, published in State Gazette, issue112 of 27.12.1995. (1995)

Ivanov, V. (2011d) Enhancing the Effectiveness of Training and Methodical Activity in Compliance with the 
New Requirements for the Military-Educational system. Report from scientific-methodological conference on 30.11.2011, Military Academy - BA, S.,

Ivanov, V. (2012b) Problems and Challenges in Front of MES in the Conditions of Economic Crisis. Report from scientific conference of National Security and Defence Faculty, held on 22-23.05.2012, Military Academy - BA, C.

Ivanov, V. (2013) Possible Approaches and Solutions for Building Intelligent System for National Security. Report from scientific conference „Security Expo”, March 6-9 2013, Military Academy - BA, C..

Academic Staff Development Act, published in State Gazette, issue 38 of May $21^{\text {st }}$ 2010. (2010b)

Regulation for applying the Academic Staff Development Act, published in State Gazette, issue 75 of September $24^{\text {th }}$ (2010c).

Dimitrova, S., V. Terziev, (2014) Система управления человеческими ресурсами для безопасности и обороны, Международная научно-практическая конференция „Иновационные процессы в научной среде", Уфа, Россия.

Competence Model in the Process of Social Adaptation of the Servicemen Dismissed from the Bulgarian Army, New Knowledge Scientific Magazine, Plovdiv, 2014, Vol.3, №3. (2014a)

Dimitrova, S., V. Terziev, (2014b) Человеческий ресурс как ключевой для обороны в секторе безопасности, Международная научно-практическая конференция 25 сентября 2014, „Инновационный вектор развития науки”, Уфа, Россия.

Dimitrova, S., V. Terziev, (2014c) Оценка и аттестация как функциональная область управления человеческими ресурсами для безопасности и обороны, Международная научно-практическая конфреренция „Перспективы развития науки”, 20 марта 2014, Уфа, Россия.

Terziev, V., S. (2015b) Dimitrova, Human resources and social activity, as engines of social development, Международный научнный журнал Иновационная наука, №4/2015, Том 3, Уфра, Россия,

Terziev, V., S. (2015c) Dimitrova, Human resources and social activity, as engines of social development, Сборник статей Международной научно-практической конференции „Прорывные экономические реформы в условиях риска и неопределености“, 10 апреля 2015г., Уфра, Аэтерна, Россия. 